\title{
26. CORRELATION BETWEEN THE CHANGES IN THE MINERALOGY, CHEMISTRY, AND MAGNETIC PROPERTIES OF BASALTS FROM DSDP LEG 46 WITH LOW TEMPERATURE SUBMARINE ALTERATION.
}

\author{
J. Honnorez, J.K. Böhlke, and B.M. Honnorez-Guerstein, Rosenstiel School of Marine and Atmospheric Science \\ University of Miami, Miami, Florida \\ and \\ N. Petersen, Institut für Allgemeine und Angewandte Geophysik, Ludwig-Maximilians Universität, München, F.R.G.
}

\begin{abstract}
Basalts from the upper 70 meters of the oceanic crust, at Site 396B of DSDP Leg 46 (about 13 my old) have been subjected to at least two main stages of low temperature alteration: (1) all of the samples studied have undergone a slight oxidation and hydration, often with introduction of calcite and smectites; (2) most of them are locally strongly oxidized and hydrated near cracks and other exposed surfaces, having lost their olivine and gained smectites, Fe-Mn oxides, phillipsite, and calcite; $\mathrm{Mg}$ and $\mathrm{Si}$ have been lost during this process. The most visible effect of the second phase of alteration, an abrupt change in rock color from gray to brown, suggests sharp chemical gradients. The least oxidized (gray) basalts essentially contain fine skeletal titanomagnetite crystals up to $5 \mu \mathrm{m}$, which always display evidences of oxidation to titanomaghemite. Larger euhedral crystals (up to $25 \mu \mathrm{m}$ ) of homogeneous titanomagnetite (unoxidized or only partly oxidized to titanomaghemite) are occasionally clustered around myarolitic voids. In the more oxidized (brown) samples, anhedral relicts of the skeletal phase sometimes remain, but they are often completely broken down. The other opaque minerals in both gray and brown samples are ubiquitous but quantitatively unimportant, and comprise one or more primary sulfide spherules, $\mathrm{Cr}$-spinel, and rare hematite overgrowths on the larger titanomagnetite crystals. Comparisons of whole rock oxidation state $\left(\mathrm{O}_{x}^{0}=\mathrm{Fe}^{3+} / \mathrm{Fe}^{2+}+\mathrm{Fe}^{3+}\right)$ for pairs of adjacent gray and brown zone samples, with Curie temperature and saturation magnetization show that (1) Curie $t^{0}$ is rather high in all of the rocks, and slightly higher in the more oxidized zones; and (2) saturation magnetization is much lower in the more oxidized zones. The high Curie $t^{0}$ indicate that titanomagnetite has been converted to titanomaghemite in all of the samples, thus accounting for the slight oxidation $\left(\mathrm{O}_{\mathrm{x}}^{0}=0.3\right)$ of the least altered rocks. This is confirmed by petrographic observation of the opaque phases and suggests that the alteration of titanomagnetite took place more readily than that of the magmatic silicate minerals. The marked decrease of the saturation magnetization in the more oxidized (brown) zones indicates that with the stronger oxidation stage $\left(\mathrm{O}_{x}^{0}=0.6\right)$, part of the titanomaghemite has been lost.
\end{abstract}

\section{INTRODUCTION}

The major drawback of prior studies of submarine alteration processes affecting sea-floor basalts is a lack of correlation between the different viewpoints of the various investigators who have separately studied changes in either the chemical, mineralogical, or magnetic properties. This situation has resulted not only from a lack of coordination between investigators, but also from the type of sampling required. It is essential for the success of cooperative projects that the same samples be analyzed by the various techniques because the danger exists that large samples generally exhibit inhomogeneities in alteration. Homogeneous samples are therefore required which must be studied by non-destructive techniques first, and by destructive techniques last.

The present study aims at correlating the effects of seafloor alteration on the mineralogy and the whole rock chemis- try with some magnetic properties and the authigenic mineral paragenesis in the top 70 meters of mid-ocean ridge (MOR) basalts in Hole 396B. Oxygen isotopes were to be measured on the same set of samples, but the data were not available at the time of writing this article.

The main objective of this paper is to compare the various degrees of oxidation of the silicate matrix of the MOR basalts with those of the magnetic oxides (i.e., the titanomagnetites). Does the oxidation proceed at the same rate in both phases, or does oxidation of the silicate and opaque phases proceed independently?

\section{SAMPLING AND SAMPLE PREPARATION}

The analyzed samples were selected on board ship mainly on the basis of their color in hand specimens. As often as possible, pairs of adjacent samples were selected from core 
fragments that exhibited both brown and gray colors. The samples displaying a brown color were obviously altered, and the gray ones appeared unaltered. However, our study proved that even these gray samples are oxidized and hydrated, and whenever the adjective fresh is used to qualify such samples, we place it between quotation marks. Homogeneous samples displaying a single uniform color, either gray or brown, were isolated by sawing and grinding off parts with other colors and veins of secondary minerals. Samples were then ground and homogenized in agate mortar under acetone.

\section{PETROGRAPHY OF TRANSPARENT MINERALS}

The rocks sampled for this study are from the uppermost 70 meters of sparsely phyric pillow basalts from lithologic Unit 1 (see Site 396 Report, this volume). The pillow interiors are composed of variolitic to intersertal basalt in which gray, relatively fresh material grades very abruptly into brown near cracks and exposed surfaces. Our study of alteration (Honnorez et al., this volume) shows that even the freshestlooking gray portions have been altered by the addition of small amounts of clay minerals and calcite, and slight oxidation. In the brown zones, further oxidation has been accompanied by destruction of olivine (whose place is taken by reddish brown Fe-oxides and/or clay minerals) and by introduction of clay minerals, Fe-Mn oxides, phillipsite, and calcite as precipitates in vugs. Cracks along which the brown oxidized zones are localized are usually filled with the same secondary minerals, which have either replaced detrital infillings or precipitated from the walls inward in the sequence smectite/Mn-Fe oxides/phillipsite/calcite. Even in the most strongly altered samples in this study, pyroxene and plagioclase still appear from optical and bulk rock X-ray observations to be unaltered.

\section{PETROGRAPHY OF OPAQUE MINERALS}

Opaque mineralogy is summarized in Table 1.

The most abundant opaque phase of the less altered (gray) basalts from Hole 396B is a fine skeletal titanomagnetite which has been affected to different degrees by oxidation, the final product of which may be titanomaghemite. It is uniformly widespread through the silicate groundmass. The grain size of these skeletal forms varies from 2 to $5 \mu \mathrm{m}$. At high magnification (up to $1200 \mathrm{x}$ ) and in oil immersion, these skeletal grains are homogeneous, and their color varies from light tan to off-white. When they show pronounced lightening in color, red-yellow to reddish internal reflections are observed; these inner reflections appear to come from the opaque mineral itself instead of being a staining of the surrounding silicates, as we observe in the most oxidized of our basalts (brown) and as it was described by Ade-Hall et al. (1976) for Leg 34 rocks.

Euhedral to subhedral grains of titanomagnetite are found frequently around miarolitic voids of the less oxidized rocks, but they are always scarce. Their size ranges from 10 to 25 $\mu \mathrm{m}$, and their color is medium tan, like a non-oxidized magnetite. Only exceptionally do they show a gradual lightening toward the edge of the grain (a sign of minor oxidation). A rim of hematite has been occasionally observed to overgrow one or more sides of the euhedral forms of titanomagnetite. In Specimen 4-1 (9), dark brown-gray cores of chrome-spinel were observed in some of the euhedral grains of titanomagnetite (Figure 1).
The main difference between the less oxidized (gray) and the more oxidized (brown) samples is that, in the latter, part or all of the opaque grains are gone. Those which still remain are anhedral, extremely fine relicts of the skeletal forms. Their sizes range from $2 \mu \mathrm{m}$ down to the limit of visibility, one-half $\mu \mathrm{m}$ or less. Their color is off-white, and yellowreddish brown staining of the surrounding silicates is common. Inner reflections were not observed in these grains, probably because of their small size.

Primary sulfides are scarce, and they occur as small $(2 \mu \mathrm{m}$ or less) rounded grains. A two-phase irregular mass, $250 \mu \mathrm{m}$ across, probably of cubanite with exsolved blebs of chalcopyrite, was observed associated with skeletal titanomagnetite [Specimen 4-2 (9)]. Specimens 4-1 (1) and 7-2 (4) contain two and one sulfide spherules, respectively. The spherules in the first sample consist of a complex assemblage; they seem to be made up by a groundmass of cubanite in which blebs of mackinawite (?) in parallel orientation and irregular masses of chalcopyrite are common. Small gray-brown grains of an unidentified phase are also included in one of these spherules. The spherule in Specimen 7-2 (4) is less complex and seems to consist of chalcopyrite or cubanite. In both specimens, the spherules are partially oxidized to geothite.

\section{BULK ROCK GEOCHEMISTRY}

The major, minor, and trace elements have been analyzed in 36 bulk rock samples (from Units 1,2, and 5 of Hole 396B) by a combination of atomic absorption, gravimetric, and colorimetric techniques (Honnorez et al., this volume). More specifically, the $\mathrm{FeO}$ content was measured by titration with potassium bichromate, whereas, the total iron content was measured by atomic absorption; the $\mathrm{Fe}_{2} \mathrm{O}_{3}$ content was then derived by subtracting the titrated $\mathrm{FeO}$ from total $\mathrm{FeO}$. The bulk rock oxidation ratio is calculated according to the following formula:

$$
\mathrm{O}_{\mathrm{X}}^{\circ}=\frac{\mathrm{Fe}_{2} \mathrm{O}_{3} / 80}{\mathrm{Fe}_{2} \mathrm{O}_{3} / 80+\mathrm{FeO} / 72}
$$

The overall oxidation ratio $\mathrm{O}_{x}^{0}$ of the MOR basalts depends on both the oxidation states of the opaque minerals and the silicate matrix since the iron content is almost equally distributed between the two. A completely oxidized rock has an oxidation ratio of 1 , whereas if a basalt without $\mathrm{Fe}_{2} \mathrm{O}_{3}$ at all could exist, its oxidation ratio would be equal to zero. Assuming that the ideal, fresh MOR tholeiite from the sparsely phyric basalt units had a maximum $\mathrm{Fe}_{2} \mathrm{O}_{3}$ content of 1.5 per cent, the oxidation ratio of such a rock would be equal to 0.14 . The oxidation ratio of samples from gray zones ranges from 0.24 to 0.35 (average of 10 samples $=0.31$ ), whereas it varies from 0.54 to 0.69 in the brown zones (average of 14 samples $=0.60$ ). One can, therefore, conclude that the gray samples are all slightly oxidized and that the brown samples are more oxidized than the gray samples, but that this oxidation is not extreme. The gap between the $\mathrm{O}_{x}^{0}$ of the brown and gray zones samples might be an artifact due to the fact that the 2 to $4 \mathrm{~mm}$-thick transition layer between the two zones could not be sampled.

By comparing chemical compositions (see details in Honnorez et al., this volume) of the gray zone samples with those of the brown zones, and the average composition of the fresh 
TABLE 1

Opaque Mineralogy Study

\begin{tabular}{|c|c|c|c|c|}
\hline \multicolumn{2}{|c|}{$\begin{array}{l}\text { Sample } \\
\text { (Interval in cm) } \\
\text { and Color }\end{array}$} & \multirow{2}{*}{$\begin{array}{c}\text { Magnetite } \\
\text { (Description, Grain Size) }\end{array}$} & \multirow{2}{*}{\begin{tabular}{l}
\multicolumn{1}{c}{$\begin{array}{c}\text { Sulfides } \\
\text { (Description, Grain Size) }\end{array}$} \\
Two large sulfide spherules: \\
Cb(?), Mw(?) and Sl(?) assemb- \\
lage; partial alteration into Fe- \\
hydroxides
\end{tabular}} & \multirow{2}{*}{$\begin{array}{r}\text { Other Phases } \\
\text { Mixed Fe-hydroxides }\end{array}$} \\
\hline $\begin{array}{l}4-1,14-17 \\
\text { (piece 1) }\end{array}$ & Brown & & & \\
\hline $\begin{array}{l}4-1,22-24 \\
\text { (piece 2) }\end{array}$ & Brown & $\begin{array}{l}\text { Extremely fine anhedral grains, light } \\
\text { brown to off-white color and red-yellow } \\
\text { IR }(2 \mu \mathrm{m} \text { or less); occasional larger } \\
\text { euhedral to subhedral tan grains, some } \\
\text { are mantle with Hem }(10 \mu \mathrm{m})\end{array}$ & $\begin{array}{l}\text { Scarce small indet. rounded grains } \\
(1.5 \mu \mathrm{m})\end{array}$ & \\
\hline $\begin{array}{l}4-1,103-105 \\
\text { (piece 9) }\end{array}$ & Gray & $\begin{array}{l}\text { Abundant fine skeletal grains, light tan } \\
\text { to off-white; some red or red-yellow } \\
\text { IR ( } 5 \mu \mathrm{m} \text { or less); occasional euhedral } \\
\text { medium brown grains }(10-15 \mu \mathrm{m}), \text { few } \\
\text { with gray core of chrome-spinel(?) }\end{array}$ & $\begin{array}{l}\text { Frequent small spherules of sulfides } \\
\text { (2); few irregular grains of Po in } \\
\text { association with euhedral magnetite } \\
(10 \mu \mathrm{m})\end{array}$ & $\begin{array}{l}\text { Chrome-spinel(?) } \\
\text { Ilm.(?) }\end{array}$ \\
\hline $\begin{array}{l}4-2,57-59 \\
(\text { piece } 9)\end{array}$ & Brown & $\begin{array}{l}\text { Extremely fine anhedral grains, light tan } \\
\text { to off-white and red-yellow IR }(1.5 \mu \mathrm{m} \text { or } \\
\text { less); occasional medium brown euhedral } \\
\text { grains }(10 \mu \mathrm{m})\end{array}$ & $\begin{array}{l}\text { Occasional two-phase irregular grains } \\
\text { of } \mathrm{Cb}(?) \text { with Cp blebs; associated } \\
\text { grains of magnetite }\end{array}$ & $\begin{array}{l}\text { One ovoidal grain of chrome-s } \\
\text { spinel similar phase }(100 \mu \mathrm{m}\end{array}$ \\
\hline $\begin{array}{l}5-1,86-88 \\
\text { (piece 9) }\end{array}$ & Gray & $\begin{array}{l}\text { Extremely fine skeletal to anhedral grains, } \\
\text { light tan to off-white and red-yellow IR } \\
(3 \mu \mathrm{m} \text { or less })\end{array}$ & & \\
\hline $\begin{array}{l}5-2,12-14 \\
\text { (piece 2) }\end{array}$ & Brown & $\begin{array}{l}\text { Extremely fine skeletal to anhedral grains, } \\
\text { off-white color and yellow-reddish IR } \\
(2 \mu \mathrm{m} \text { or less })\end{array}$ & $\begin{array}{l}\text { Scarce anhedral grains of one and two } \\
\text { phases yellow sulfides (Po and Cp?); } \\
\text { size range from } 15 \text { to } 3 \mu \mathrm{m}\end{array}$ & \\
\hline $\begin{array}{l}5-2,28-31 \\
(\text { piece 4) }\end{array}$ & $\begin{array}{l}\text { Gray to } \\
\text { brown }\end{array}$ & $\begin{array}{l}\text { Extremely fine anhedral grains (1); occa- } \\
\text { sional larger euhedral medium tan grains } \\
\text { (up to } 10 \mu \mathrm{m} \text { with adjacent spherules of } \\
\text { Py(?) }\end{array}$ & Scarce indet. rounded grains $(2 \mu \mathrm{m})$ & \\
\hline $\begin{array}{l}5-2,32-24 \\
\text { (piece } 5)\end{array}$ & Gray & $\begin{array}{l}\text { Fine skeletal and anhedral grains, light } \\
\text { tan to white-off color and red to red- } \\
\text { yellow IR }(7 \mu \mathrm{m})\end{array}$ & & $\operatorname{Ilm}(?)$ \\
\hline $\begin{array}{l}6-1,55-57 \\
\text { (piece 7) }\end{array}$ & Gray & $\begin{array}{l}\text { Fine skele tal to anhedral grains, light tan } \\
\text { to off-white, red-to red-yellow IR (5); } \\
\text { occasional larger subhed ral grains, med- } \\
\text { ium tan and lightening of the edges } \\
(15-18 \mu \mathrm{m})\end{array}$ & & $\begin{array}{l}\text { Lath-shape grains of oxidized } \\
\text { Ilm(?), red IR }\end{array}$ \\
\hline $\begin{array}{l}6-1,109-111 \\
(\text { piece } 14)\end{array}$ & Brown & $\begin{array}{l}\text { Extremely fine anhedral grains off white } \\
\text { color }\end{array}$ & & \\
\hline $\begin{array}{l}7-1,142-144 \\
\text { (piece } 12 \text { ) }\end{array}$ & $\begin{array}{l}\text { Gray to } \\
\text { brown }\end{array}$ & $\begin{array}{l}\text { Fine skeletal to anhedral grains, mostly } \\
\text { off-white color and red-yellow IR }(5 \mu \mathrm{m}) ; \\
\text { few larger euhedral tan grains ( } 10 \text { to } 40 \mu \mathrm{m})\end{array}$ & $\begin{array}{l}\text { Very scarce rounded indet grains } \\
(2 \mu \mathrm{m})\end{array}$ & \\
\hline $\begin{array}{l}7-2,34-36 \\
(\text { piece } 4)\end{array}$ & Brown & $\begin{array}{l}\text { Extremely fine anhedral grains, off-white } \\
\text { color and orange-yellow IR }(2 \mu \mathrm{m})\end{array}$ & $\begin{array}{l}\text { Spherule of Cp partly oxidized into } \\
\text { Fe-hydroxide ( } 40 \mu \mathrm{m} \text { across) }\end{array}$ & \\
\hline $\begin{array}{l}7-2,47-49 \\
\text { (piece } 5 \text { ) }\end{array}$ & Brown & $\begin{array}{l}\text { Extremely fine anhedral grians, off- } \\
\text { white color }(1.5 \mu \mathrm{m})\end{array}$ & $\begin{array}{l}\text { Few irregular masses of } \mathrm{Cp}(?) \text { in the } \\
\text { groundmass and one such grain inside } \\
\text { narrow vein (grain size up to } 10 \mu \mathrm{m} \text { ) }\end{array}$ & \\
\hline $\begin{array}{l}7-2,96-98 \\
\text { (piece } 9)\end{array}$ & Brown & $\begin{array}{l}\text { Fine skeletal to anhedral grains, off-white } \\
\text { color and some red-yellow IR }(1 \mu \mathrm{m})\end{array}$ & Scarce rounded indet. grains $(1.5 \mu \mathrm{m})$ & \\
\hline $\begin{array}{l}8-1,62-64 \\
(\text { piece } 8 A)\end{array}$ & Gray & $\begin{array}{l}\text { Abundant fine skeletal to anhedral grains, } \\
\text { medium tan to off-white color and red to } \\
\text { red-yellow IR ( } 5 \text { or less); occasional euhe- } \\
\text { dral to subhedral grains, medium tan } \\
\text { color }(20 \text { to } 25 \mu \mathrm{m}) \text {; hem fringe on some } \\
\text { euhedral Mt }\end{array}$ & $\begin{array}{l}\text { Frequent rounded indet. grains }(1.5 \mu \mathrm{m}) \text {; } \\
\text { relicts of } \mathrm{Cp}(?)\end{array}$ & $\begin{array}{l}\text {; Occasional lath-shape Ilm(?) } \\
\text { grains; Hem growths on Mt; } \\
\text { frequent development of Fe- } \\
\text { hydroxides with relicts of } \\
\text { Cp(?) }\end{array}$ \\
\hline $\begin{array}{l}8-1,118-120 \\
\text { (piece } 13 \text { ) }\end{array}$ & $\begin{array}{l}\text { Gray to } \\
\text { Brown }\end{array}$ & $\begin{array}{l}\text { Extremely fine skeletal to anhedral grains, } \\
\text { off-white color and red-yellow IR ( } 2) \text {; } \\
\text { occasional larger euhedral grains (up to } \\
6 \mu \mathrm{m}) \text {, medium tan color }\end{array}$ & Very scarce indet. grains & \\
\hline
\end{tabular}


TABLE 1 - Continued

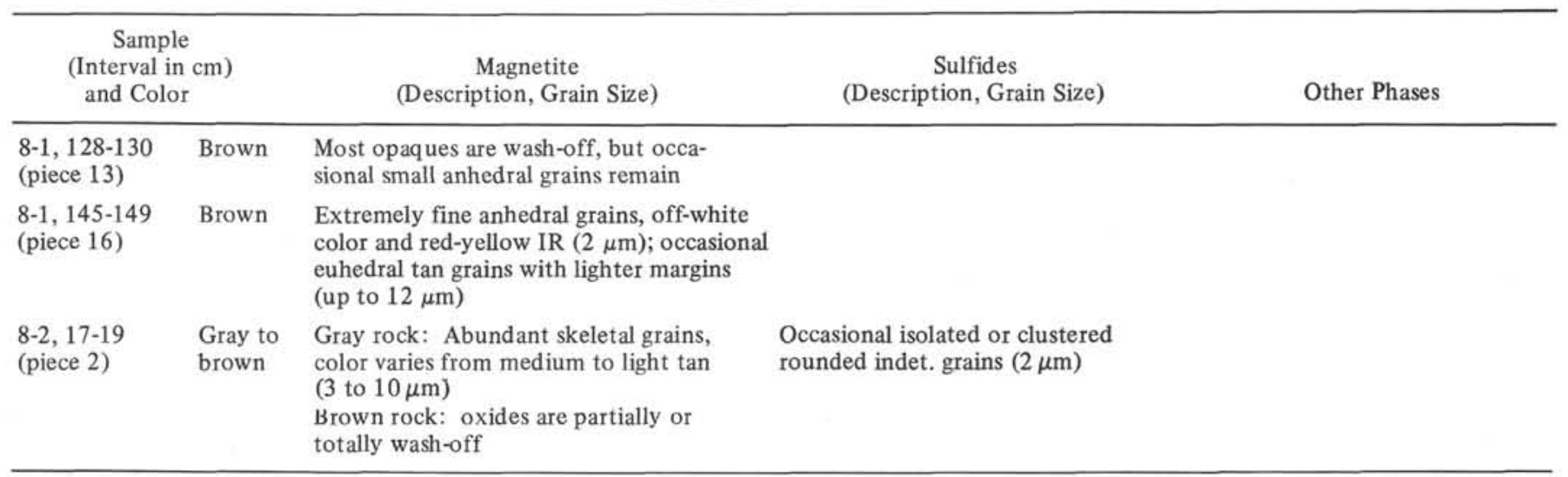

Note: Abbreviations are as follows: $\mathrm{Bn}=$ Bornite, $\mathrm{Cb}=$ Cubanite, $\mathrm{Cp}=$ Chalcopyrite, $\mathrm{Cv}=$ Covellite, Hem $=$ Hematite, Ilm $=\mathrm{Ilmenite}, \mathrm{IR}=\mathrm{In}$ ternal reflections, $\mathrm{Mw}=$ Mackinawite, $\mathrm{Po}=$ Pyrrhotite, $\mathrm{Sl}=$ Sphalerite .

glasses from the same units computed from other investigators, contributions to this volume (Sato et al.; Dungan et al.), one can conclude that the sea-floor alteration at Hole $396 \mathrm{~B}$ is essentially a hydration and oxidation process combined with a remobilization in the authigenic minerals of $\mathrm{Mg}, \mathrm{Si}, \mathrm{Ca}, \mathrm{Fe}, \mathrm{Mn}$, and to a lesser degree, $\mathrm{Na}$ and $\mathrm{K}$. The $\mathrm{MgO}$ content of the brown rocks decreases by half on average, and $\mathrm{SiO}_{2}$ by a much smaller amount; these losses are mainly attributed to the destruction of olivine, principally in the matrix and partly in the phenocrysts. When compared to the average $\mathrm{K}_{2} \mathrm{O}$ content of fresh glasses analyzed by electron microprobe $(0.12 \%)$, one can conclude that the average $\mathrm{K}_{2} \mathrm{O}$ content has increased in the gray zones that we have studied to $0.18 \%(0.21 \%$ average according to Sato et al. and Dungan et al., this volume) and to $0.19 \%$ in the brown zones. However, the variation of potassium contents between adjacent gray and brown zones within the various pairs of samples is irregular, and shows only a very weak trend toward a slight increase with oxidation and hydration.

\section{METHOD OF DETERMINATION OF THE OXIDATION STATE OF THE TITANO-MAGNETITES}

As described in the papers on low-temperature alteration of basalts (Honnorez et al., this volume) and rock magnetism (Petersen, this volume), the titanomagnetites in all the basalt samples so far investigated are altered by low temperature processes. No sign of high temperature alteration has been observed so far as lithologic Units $1,2,4$, and 5 are concerned.

The process of low temperature oxidation of titanomagnetites (maghematization) has been studied by Readman and O'Reilly (1972) and others, and can be schematically represented in the following manner:

low temperature oxidation inversion

stoichiometric $\rightarrow$ titanomaghemite $\rightarrow$ hematite + rutile + sphene titanomagnetite (cation deficient) $(+\mathrm{Si}, \mathrm{Ca})$

According to Readman and O'Reilly (1972), lowtemperature oxidation of titano-magnetite results in an increase in the Curie temperature that is in first order approximation proportional to the degree of oxidation. The saturation magnetization decreases slightly during this process.
The replacement of unstable cation-deficient titanomaghemite by a mixture of stable hematite, rutile, and possibly sphene, causes a drastic drop of the intensity of magnetization as the saturation magnetization of hematite is smaller than that of titanomaghemite by a factor of about 100 (rutile and sphene are essentially non-magnetic). Measurement of Curie temperature and saturation magnetization of the oxidized titanomagnetites can, therefore, be used to determine in a semi-quantitative way their oxidation state. As the silicate matrix of the rocks is non-magnetic and does not contribute to the overall magnetization of the rocks, it is not necessary to extract the magnetic ore component for these measurements.

The curie temperature $\left(\mathrm{T}_{\mathrm{c}}\right)$ and saturation magnetization (Is) were determined by measuring the temperature dependence of the strong-field magnetization of the powdered rock (sample size about $200 \mathrm{mg}$ ) using a magnetic balance. The measurements were carried out in air, with an applied field of 1800 Oe.

\section{RESULTS OF THE MAGNETIC MEASUREMENTS}

The results of the magnetic measurements are presented in Tables 2 and 3 and Figures 2, 3, and 4.

The plot of the overall oxidation state of the rock $\left(\mathrm{O}_{x}^{0}\right)$ against the Curie temperature (Figure 2) shows only a slight increase in $\mathrm{T}_{\mathrm{c}}$ with increasing $\mathrm{O}_{\mathrm{r}}^{0}$ for most of the samples, whereas, the saturation magnetization distinctly decreases with increasing $\mathrm{O}_{x}^{0}$ (Figure 3 ). These trends are clearly distinguishable also for the mean values (see Table 3 ). There is no correlation between Curie Tc temperature and saturation magnetization Is (Figure 4).

\section{DISCUSSION}

If we want to interpret the Curie temperature in terms of degree of oxidation of the titanomagnetites (maghemitization) we have to know what Curie temperature the original, non-oxidized titanomagnetites had. There are two possible ways to achieve this:

(1) by analyzing the chemical composition of the titanomagnetites and calculating the corresponding Curie temperature of the stoichiometric compound.

(2) by reducing the titanomaghemite back to the original stoichiometric titanomagnetite by heating the sample up to $1000^{\circ} \mathrm{C}$ under the appropriate oxygen fugacity conditions. 

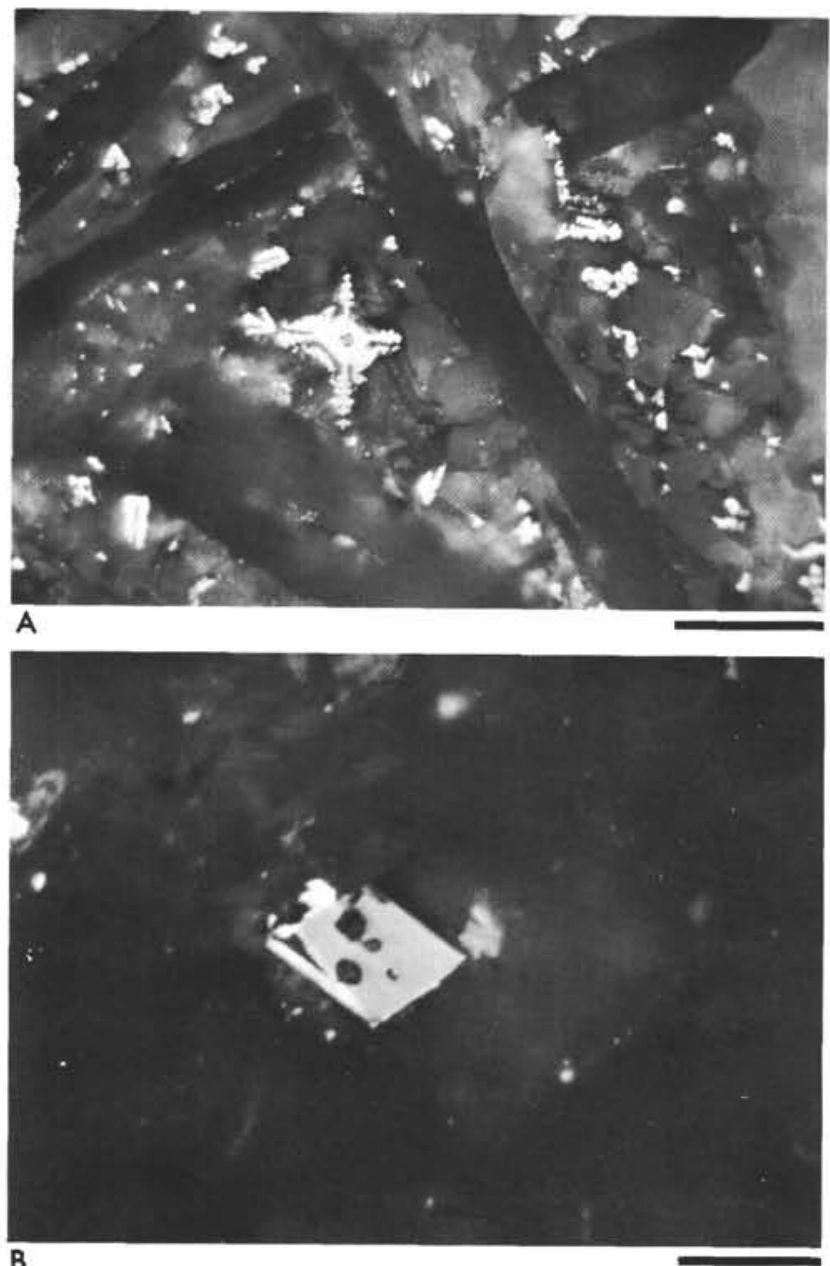

Figure 1. (A) Photomicrograph of polished section /oil immersion, 490x) of Sample 4-1 (9). Fine skeletal and anhedral grains of titanomagnetite more or less oxidized to probably titanomaghemite (white) in a gray basalt. A large skeletal titanomagnetite crystal, at the center, with chrome-spinel core (light gray). Scale bar $=30 \mu \mathrm{m}$. (B) Microphotograph of polished section (oil immersion, $610 x)$ of Sample 8-1 (8A). One euhedral grain of homogeneous titanomagnetite (gray) rimed by hematite (white) overgrowth and adjacent hematite needle. Scale bar $=20 \mu \mathrm{m}$.

As the grain size of the titanomagnetites of the investigated rocks is too small, no microprobe analysis to determine their chemistry has been attempted. However, the range of the primary composition of titanomagnetites in tholeiitic basalts is generally very narrow. It seems, therefore, legitimate to use the mean value of Curie temperatures of non-oxidized, primary titanomagnetites in tholeiitic basalts, which is $100^{\circ} \mathrm{C}$ (Petersen, 1976).

For the titanomagnetite reduction method, three different samples were selected that obviously showed the lowest degree of oxidation. This seems to be essential as the microscopic observation in reflected light (Honnorez et al., this volume) gives evidence for cation migration out of the strongly oxidized titanomaghemites and would in this case lead to a stoichiometric titanomagnetite different in composition from that of the initial titanomagnetite.
TABLE 2

Results of Magnetic Measurements

\begin{tabular}{|c|c|c|c|c|}
\hline $\begin{array}{c}\text { Sample } \\
\text { (Interval in } \mathrm{cm} \text { ) }\end{array}$ & Color & $\mathrm{O}_{\mathrm{x}}^{\circ}$ & $\operatorname{Tc}\left({ }^{\circ} \mathrm{C}\right)$ & $\mathrm{I}\left(\times 10^{2} \mathrm{emu} / \mathrm{g}\right)$ \\
\hline $\begin{array}{l}4-1,14-17 \\
\text { (piece 1) }\end{array}$ & Brown & 0.69 & 350 & 8 \\
\hline $\begin{array}{l}4-1,22-24 \\
\text { (piece 2) }\end{array}$ & Brown & 0.60 & 315 & 13 \\
\hline $\begin{array}{l}4-2,62-64 \\
\text { (piece } 9 \text { ) }\end{array}$ & Gray & 0.30 & 280 & 16.5 \\
\hline $\begin{array}{l}4-2,57-59 \\
\text { (piece } 9 \text { ) }\end{array}$ & Brown & 0.57 & 385 & 9.5 \\
\hline $\begin{array}{l}5-2,9-11 \\
\text { (piece 2) }\end{array}$ & Gray & 0.29 & 305 & 13.5 \\
\hline $\begin{array}{l}5-2,12-14 \\
\text { (piece 2) }\end{array}$ & Brown & 0.57 & 325 & 13 \\
\hline $\begin{array}{l}\text { 6-1, 109-111 } \\
\text { (piece 4) }\end{array}$ & Brown & 0.65 & 380 & 4.5 \\
\hline $\begin{array}{l}7-1,145-147 \\
\text { (piece } 12 \text { ) }\end{array}$ & Gray & 0.34 & 285 & 17 \\
\hline $\begin{array}{l}7-2,34-36 \\
(\text { piece 4) }\end{array}$ & Brown & 0.59 & 410 & 8.5 \\
\hline $\begin{array}{l}7-2,47-49+48-50 \\
\text { (piece 5) }\end{array}$ & Gray & 0.33 & 295 & 13 \\
\hline $\begin{array}{l}7-2,47-49+48-50 \\
\text { (piece 5) }\end{array}$ & Brown & 0.63 & 300 & 8.5 \\
\hline $\begin{array}{l}7-2-96-98 \\
(\text { piece 9) }\end{array}$ & Gray & 0.27 & 305 & 11 \\
\hline $\begin{array}{l}7-2,96-98 \\
\text { (piece } 9 \text { ) }\end{array}$ & Brown & 0.60 & 345 & 6.5 \\
\hline $\begin{array}{l}8-1,118-120 \\
\text { (piece 13) }\end{array}$ & Gray & 0.34 & 335 & 12 \\
\hline $\begin{array}{l}8-1,118-120 \\
\text { (piece 13) }\end{array}$ & Brown & 0.60 & 350 & 6.5 \\
\hline $\begin{array}{l}8-1,114-116 \\
\text { (piece 13) }\end{array}$ & Brown & 0.60 & 275 & 9 \\
\hline $\begin{array}{l}8-1,145-149 \\
\text { (piece 16) }\end{array}$ & Brown & 0.56 & 300 & 13.5 \\
\hline $\begin{array}{l}8-2,17-19 \\
\text { (piece 2) }\end{array}$ & Gray & 0.29 & 315 & 20 \\
\hline $\begin{array}{l}8-2,17-19 \\
\text { (piece 2) }\end{array}$ & Brown & 0.56 & 325 & 14 \\
\hline $\begin{array}{l}12-1,9-11 \\
\text { (piece 1) }\end{array}$ & Gray & 0.35 & 295 & 16.5 \\
\hline $\begin{array}{l}12-1,27-29 \\
\text { (piece 3) }\end{array}$ & Brown & 0.60 & 290 & 9 \\
\hline
\end{tabular}

TABLE 3

Mean Values of Whole Rock Oxidation State $\left(\mathrm{O}_{\mathrm{x}}^{\circ}\right)$, Curie Temperature (Tc), and Saturation Magnetization (Is)

\begin{tabular}{lcccc}
\hline $\begin{array}{l}\text { Rock } \\
\text { Color }\end{array}$ & $\begin{array}{c}\text { Number of } \\
\text { Samples }\end{array}$ & $\mathrm{O}_{\mathrm{X}}^{\circ}$ & $\mathrm{Tc}\left({ }^{\circ} \mathrm{C}\right)$ & Is $\left(10^{-2} \frac{\mathrm{emu}}{\mathrm{g}}\right)$ \\
\hline Gray & 8 & $0.31 \pm 0.03$ & $302 \pm 17$ & $15 \pm 3$ \\
Brown & 15 & $0.60 \pm 0.03$ & $336 \pm 38$ & $9 \pm 3$ \\
\hline
\end{tabular}

The samples were heated at $1000^{\circ} \mathrm{C}$ in an oxygen fugacity of $10^{-10} \mathrm{~atm}$ for increasing periods of time up to 2 hours. After each heating cycle, the temperature of the thus reduced titanomagnetite was $105^{\circ}, 107^{\circ}$, and $110^{\circ} \mathrm{C}$, respectively.

It is evident that both methods (1) and (2) yield about the same value of $110^{\circ} \mathrm{C}$ for the Curie temperature of the original non-oxidized titanomagnetites in our rocks. The difference between the actually measured $\mathrm{T}_{\mathrm{c}}$ of an invididual rock sample and the original value $110^{\circ} \mathrm{C}$ is the measure of oxidation state of the titanomagnetite used in this paper.

The most striking result thus obtained is the fact that most of the titanomagnetites in all samples have undergone a 


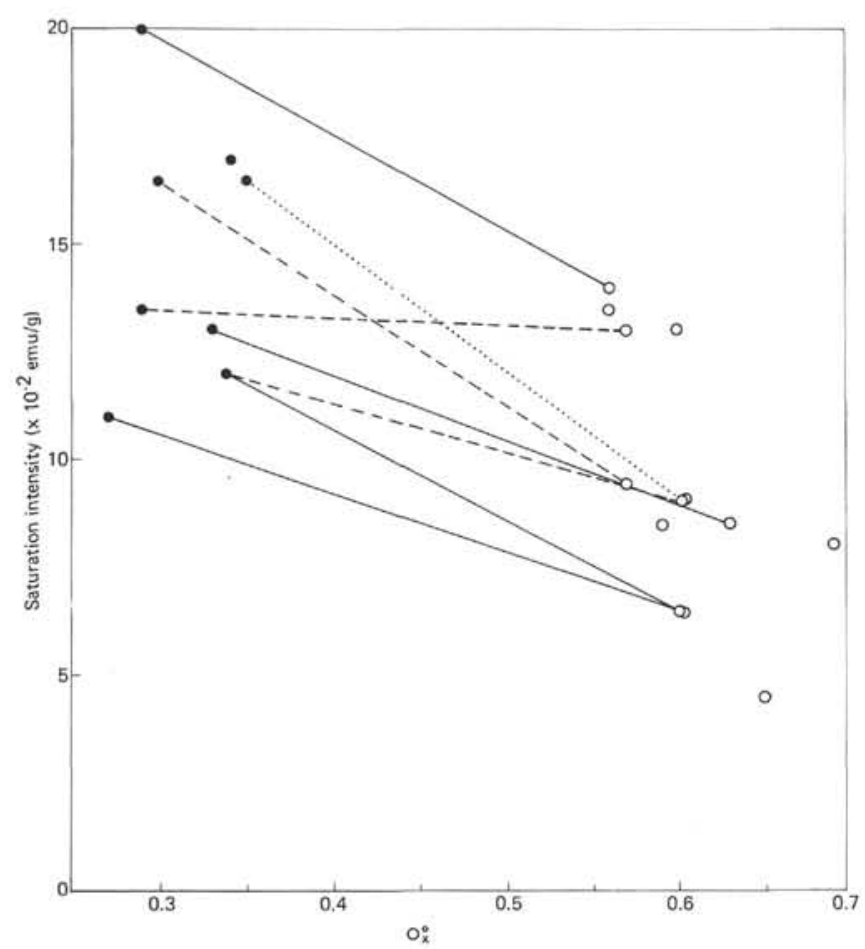

Figure 2. Curie temperature (Tc) in ${ }^{\circ} \mathrm{C}$ versus oxidation ratio $\left(O_{x}^{\circ}\right)$ of basalt samples from Hole 396B, Leg 46. Filled circles $=$ gray zone samples, open circles $=$ brown zone samples. Solid tie-lines connect pairs of brown and gray samples immediately adjacent to each other. Dashed tie-lines connect pairs of brown and gray samples from different parts of the same core fragment. Spaced dashed tie-lines connect pairs of brown and gray samples from different core fragments.

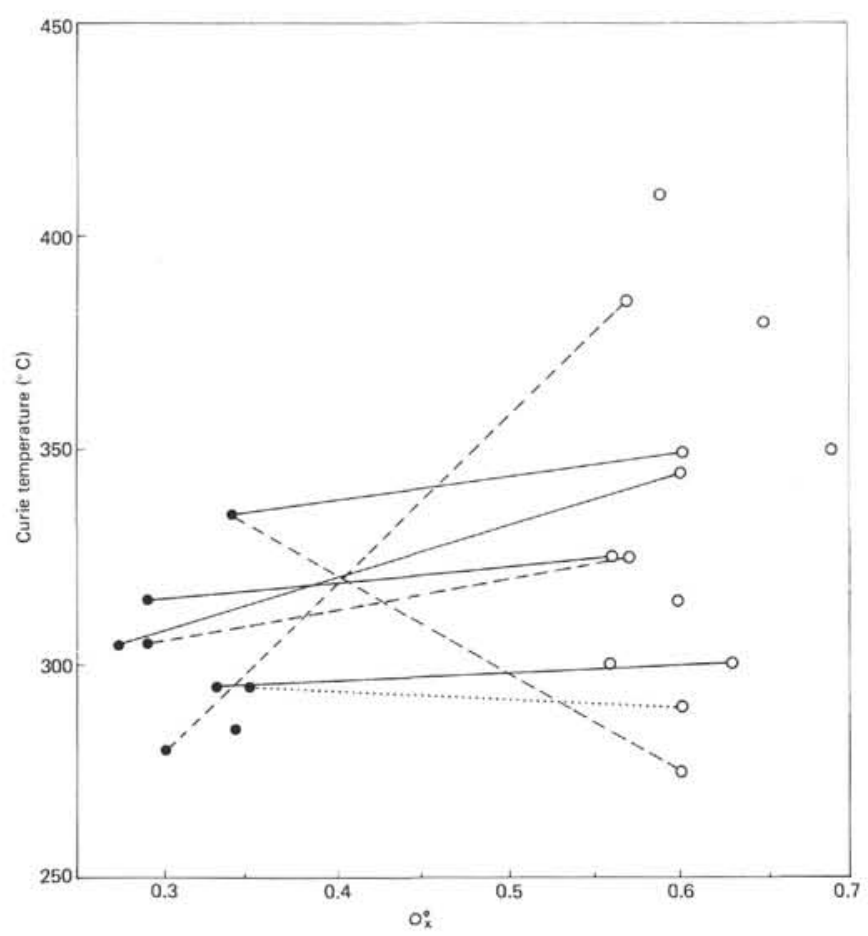

Figure 3. Saturation intensity (Is) in $10^{-2}$ emu/g versus oxidation ratio $\left(O_{x}^{\circ}\right)$ of basalt samples from Hole $396 \mathrm{~B}$, Leg 46. (Same legend as Figure 2.)

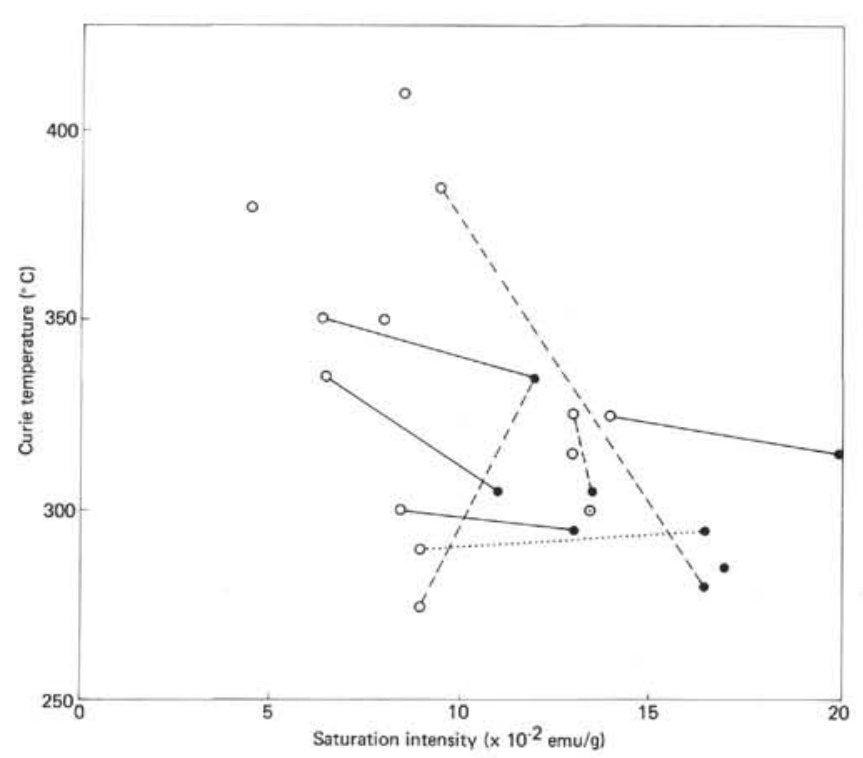

Figure 4. Curie temperature $(T c)$ in ${ }^{\circ} \mathrm{C}$ versus saturation intensity (Is) in $10^{-2} \mathrm{emu} / \mathrm{g}$ of basalt samples from Hole 396B, Leg 46. (Same legend as Figure 2.)

considerable amount of oxidation. Furthermore, this titanomagnetite oxidation does not show strong correlation with the overall oxidation state of the rock (see Figure 2). It seems therefore very likely to us that the oxidation of titanomagnetite proceeds at a much faster rate than alteration of the silicates, and may already play an important role for very young ocean floor basalts. This is in accordance with other studies (e.g., FAMOUS, Johnson and Atwater, 1977 ), which suggest that the oxidation of titanomagnetite occurs within a few hundred thousand years after lava has been erupted on the sea floor.

On the other hand, the alteration of the titanomaghemite (with associated decrease of intensity of magnetization) into secondary products (with very low or no magnetization) is obviously correlated with the alteration of the rocks (see Figure 3).

\section{ACKNOWLEDGMENTS}

The magnetic measurements described in this paper have been carried out at the Institut F.A.u.A Geophysik of the University of Munich. We should like to thank Professor Dr. G. Angen Meister, Director of this Institute, for making available the facilities of his institute and supporting this study. This study has been supported by the Deutsche Forschungsgemeinschaft and by the National Science Foundation (NSF Grant OCE 76-82154).

\section{REFERENCES}

Ade-Hall, J., Fink, L.K., Johnson, H.P., 1976. Petrography of opaque minerals, Leg 34. In Yeats, R.S., Hart, S.R., et al., Initial Reports of the Deep Sea Drilling Project, Volume 34: Washington (U.S. Government Printing Office), p. 349-362.

Johnson, H. P. and Atwater, T., 1977. Magnetic study of basalts from the mid-Atlantic Ridge, Lat $37^{\circ} \mathrm{N}$, Geol. Soc. Am. Bull., v. 88 , p. $637-647$.

Petersen, H., 1976. Notes on the variation of magnetization within basalt flows and dikes, Pageoph., v. 114.

Readman. P.W. and O'Reilly, W., 1972. Magnetic properties of oxidized (cation deficient) titanomagnetite ( $\mathrm{Fe}, \mathrm{Ti}, \square)_{3} \mathrm{O}_{4}, J$. Geomag. Geoelect. v. 24, p. 69-90. 